\title{
Dynamics of leaf, flower and fruit abscission in avocado cv. Hass in Antioquia, Colombia
}

\section{Dinámica en absición de hojas, flores y frutos en aguacate cv. Hass en Antioquia, Colombia}
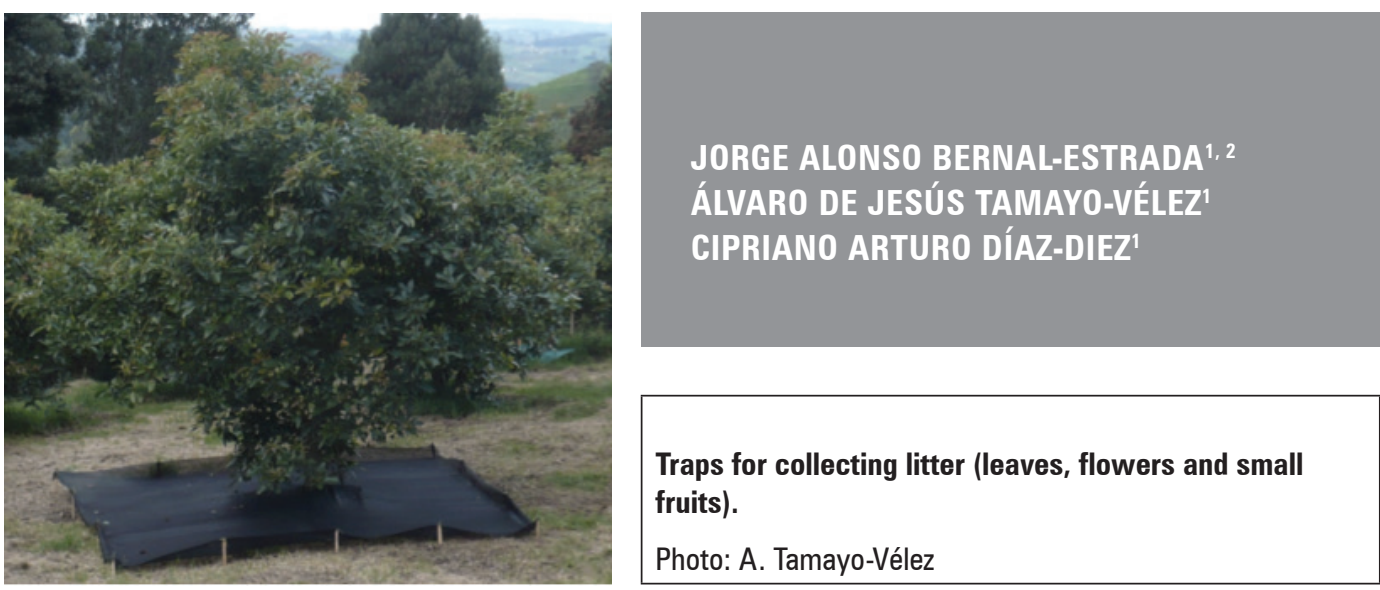

\begin{abstract}
The amount of leaf litter produced by avocado trees cv. Hass is an important potential source of mineral resources, and quantifying its production and nature is crucial to understanding the cycling of nutrients. The main objective of this study was to quantify the production of leaf litter and fallen flowers and small fruits in avocado orchards at eight locations in three producing areas in the Department of Antioquia (west, southwest, and north). The highest leaf litter production occurred in southwest Antioquia, at Jardin ( $7.6 \mathrm{t}$ ha ${ }^{-1}$ year $\left.^{-1}\right)$; the east locations had similar leaf fall (4.03-3.4 $\left.\mathrm{t} \mathrm{ha}^{-1} \mathrm{year}^{-1}\right)$. The dry matter produced in the north was very similar in both locations. The dry matter was $2.8 \mathrm{t} \mathrm{ha}^{-1}$ year ${ }^{-1}$. Higher leaf litter was recorded in all locations during the driest periods. Approximately $80 \%$ of the fallen fruits had diameters less than $1 \mathrm{~cm}$. The highest flower production and fall occurred in southwest Antioquia, followed by the northern region.
\end{abstract}

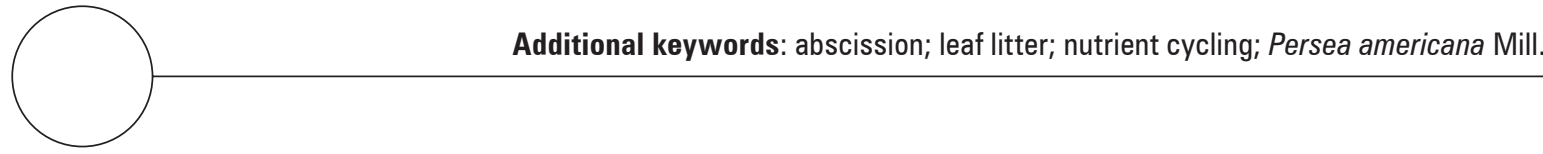

\footnotetext{
1 Corporación Colombiana de Investigación Agropecuaria - Agrosavia, La Selva Research Center, Rionegro (Colombia). ORCID Bernal-Estrada, J.A.: 0000-0003-4392-0766; ORCID Tamayo-Vélez, A.J.: 0000-0002-2765-742X; ORCID DíazDiez, C.A.: 0000-0002-7952-600X

2 Corresponding author.jbernal@agrosavia.co
} 


\section{RESUMEN}

La cantidad de hojarasca producida por árboles de aguacate cv. Hass constituyen una importante fuente potencial de recursos minerales, por lo que la cuantificación de su producción y naturaleza son cruciales para comprender el ciclaje de nutrientes. El objetivo principal de este estudio fue cuantificar la producción de hojarasca, flores y frutos pequeños caídos, en huertos de aguacate, en ocho localidades y en tres zonas productoras del departamento de Antioquia (Oriente, Suroeste y Norte). La mayor producción de hojarasca se presentó en el Suroeste antioqueño, siendo superior en Jardín (7,6 t ha $\mathrm{a}^{-1}$ año-1); las localidades del oriente presentaron caída de hojas similares (4,03- 3,4 $\left.\mathrm{t} \mathrm{ha} \mathrm{a}^{-1} \mathrm{añ} \mathrm{O}^{-1}\right)$. La materia seca producida en el norte fue muy similar en ambas localidades. La materia seca obtenida fue de 2,8 $\mathrm{t} \mathrm{ha}^{-1}$ año-1 Los mayores aportes de hojarasca en todas las localidades se presentaron durante las épocas más secas. Se encontró que aproximadamente el $80 \%$ de los frutos caídos corresponden a diámetros menores a $1 \mathrm{~cm}$. Las mayores producciones y caída de flores se presentaron en las localidades del suroeste Antioqueño, seguido de la región del norte.

Palabras clave adicionales: abscision; hojarasca; ciclaje de nutrientes; Persea americana Mill.

Received for publication: 10-04-2020 Accepted for publication: 23-11-2020

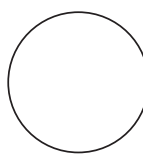

INTRODUCTION

Worldwide, avocados (Persea americana Mill.) are cultivated in a wide range of climates (Dreher and Davenport, 2013; Ramírez-Gil et al., 2020). According to the Food and Agriculture Organization (FAO,2019), avocado harvest increased to 6.4 million $t$ in 2018, and more than $86 \%$ was obtained in developing countries. Latin America and the Caribbean will become the main producing regions because Mexico and Chile are two of the larger exporters of avocado, and Peru and Colombia gaining ground in this market. The departments with the larger cultivated areas for Hass avocado in Colombia are Antioquia with 17,107 ha, Tolima with 13,603 ha, Caldas with 11,189 ha, Valle del Cauca with 4,661 ha, and Risaralda with 5,578 ha (MADR, 2019).

The vigor of tree growth and fruit production depends on the timing and extent of phenological events, which are controlled by the availability of carbon and energy and their distribution in response to environmental conditions (Charrier et al., 2015; Henao-Rojas et al., 2019; Tixier et al., 2020). Avocado leaves require about $40 \mathrm{~d}$ from bud-break to transition from net carbon importers (sinks) to net carbon exporters (sources) (Schaffer et al., 2015; Salazar-García et al., 2015). Cultivated avocado trees are mostly of persistent leaf, despite the surprisingly short longevity of its leaves, ranging from 10 to 12 months (Whiley and Schaffer, 1994). Some cultivars are more prone to defoliation just before flowering, especially in environments that impose a stress, e.g. drought, soil salinity, and root infection by Phytophthora cinnamomi (Whiley, 1994). Litter decomposition is the set of physical and chemical processes that reduce the basic chemical constituents and is the most important process of nutrient recycling in any ecosystem because the decomposition of litter makes nutrients available to plants (Castellanos and León, 2011).

One of the limitations to avocado production is that, in Colombia, crops are planted in soils that are mostly strong to extremely acid and poor in nutrients (Tamayo and Osorio, 2014; Henao-Rojas et al., 2019). This is usually corrected with high doses of calcium, organic amendments, and fertilizers, not only in at establishment but also in the vegetative and productive period (Castellanos and Léon, 2011). A continuous contribution to soil of nutrients contained in leaf litter through decomposition is one of the natural methods of renewal and maintenance in ecosystems. The accumulation of plant residues on the surface of the soil has positive effects on productivity, as has been demonstrated in several studies on the positive effect of such inputs and the decomposition processes of leaf litter, both in natural systems and in agricultural or forestry production (Loydi et al., 2014; Gaspar-Santos et al., 2015; Fuentes et al., 2018; Alvarado-Solano and Otero, 2015).

The hypothesis stated that quantifying the production and nature (leaves, flowers and small fruits) of leaf litter is crucial to understanding the potential 
contribution of nutrients and participation in the cycling of nutrients. Since there is no information at the global level on the quantification of the litter amount provided by the cultivation of avocado cv. Hass under the conditions of highland tropics, a study was established to quantify the production of leaf litter, flower drop and small fruits in avocado orchards cv. Hass at eight locations in three producing areas of the Department of Antioquia (east, southwest and north), Colombia. The contribution of nutrients in the litter and the correlation between the phenology and climatology at the evaluation sites were not determined.

\section{MATERIALS AND METHODS}

The present study was carried out by the Corporación Colombiana de Investigación Agropecuaria - Agrosavia on five-year-old adult avocado cv. Hass trees, grafted on Antillean rootstocks, at eight locations in the Department of Antioquia (Tab. 1). The trees were similar in age, development and canopy volume. At the beginning of the research, a soil analysis was carried out following the standards required by specialized laboratories to reveal the chemical characteristics of the soil at each location.

\section{Leaf litter production, fall flower and fruit fall}

The leaf litter production was evaluated in 18 trees in each location. Leaf litter traps were installed, which were made from plastic mesh with a maximum retention of light (80\%), area of $5 \times 4 \mathrm{~m}$ and $20 \mathrm{~cm}$ above the ground (size of the tree canopy projected on the ground). The fallen leaf, flower and fruit litter was collected weekly for 22 months and dried in an oven at $65^{\circ} \mathrm{C}$ until constant weight; then, the dry mass was determined per month.

Automated weather stations, SpecWare 9 Pro ${ }^{\circledR}$, Spectrum Technologies Inc. (Version 9.03 Build 0240), were installed on each farm, in which relevant weather conditions were recorded for 22 months. However, this study only determined the effect of precipitation on leaf fall.

\section{Statistical analysis}

A completely randomized block design was used, with three blocks containing six trees each, for a total of 18 trees sampled, on eight farms (locations) (treatments) in the Department of Antioquia. The difference in means was analyzed with Tukey's test $(P \leq 0.05)$ after analysis of variance. The evaluated variables were production per plant of leaf litter, number of fallen flowers and fruits by size $(<0.5 ; 0.5$ 1 ; $1-2 ; 2-3 ; 3-4 ; 4-5$ and $5-6 \mathrm{~cm}$ in diameter).

\section{RESULTS AND DISCUSSION}

The soil analysis at the different locations indicated that the soil ranged from acidic to strongly acidic $\mathrm{pH}$, with a medium content of organic matter, low contents of $\mathrm{P}, \mathrm{Ca}, \mathrm{Mg}, \mathrm{K}$ and $\mathrm{B}$ and low fertility (Tab. 2).

The contributions of the leaf litter varied considerably according to the ecosystem; in this sense, the leaf fall of the trees in some locations was statistically

Table 1. Description of geographical characteristics of the locations.

\begin{tabular}{|l|c|c|c|c|c|}
\hline \multirow{2}{*}{ Location } & Subregion & Altitude & Planting distance & \multicolumn{2}{|c|}{ Latitude-longitude } \\
\cline { 4 - 6 } & & $(\mathrm{m}$ a.s.I. $)$ & $\mathrm{N}$ & W \\
\hline El Retiro 1 & East & 2,442 & $7 \times 5$ & $06^{\circ} 01^{\prime} 46.5^{\prime \prime}$ & $75^{\circ} 27^{\prime} 28.0^{\prime \prime}$ \\
\hline El Retiro 2 & East & 2,295 & $7 \times 7$ & $06^{\circ} 02^{\prime} 51.0^{\prime \prime}$ & $75^{\circ} 29^{\prime} 45.4^{\prime \prime}$ \\
\hline Rionegro & East & 2,165 & $7 \times 5$ & $06^{\circ} 06^{\prime} 07.2^{\prime \prime}$ & $75^{\circ} 26^{\prime} 33.4^{\prime \prime}$ \\
\hline El Peñol & East & 1,995 & $7 \times 8$ & $06^{\circ} 11^{\prime} 42.9^{\prime \prime}$ & $05^{\circ} 13^{\prime} 57.7^{\prime \prime}$ \\
\hline Amaga & Southwest & 1,796 & $5 \times 5$ & $06^{\circ} 01^{\prime} 39.9^{\prime \prime}$ & $75^{\circ} 40^{\prime} 34.2^{\prime \prime}$ \\
\hline Jardin & Southwest & 2,037 & $7 \times 4$ & $05^{\circ} 35^{\prime} 51.1^{\prime \prime}$ & $75^{\circ} 48^{\prime} 17.0^{\prime \prime}$ \\
\hline San Pedro 1 & North & 2,471 & $7 \times 7$ & $06^{\circ} 29^{\prime} 25.0^{\prime \prime}$ & $75^{\circ} 31^{\prime} 28.1^{\prime \prime}$ \\
\hline San Pedro 2 & North & 2,413 & $8 \times 8$ & $06^{\circ} 29^{\prime} 41.8^{\prime \prime}$ & $75^{\circ} 31^{\prime} 09.5^{\prime \prime}$ \\
\hline
\end{tabular}


Table 2. Chemical characteristics of the soils on the farms in the evaluated municipalities.

\begin{tabular}{|c|c|c|c|c|c|c|c|c|c|c|c|c|c|c|}
\hline \multirow{2}{*}{ Location } & $\mathrm{pH}$ & MO & $\mathrm{Al}$ & $\mathrm{Ca}$ & $\mathrm{Mg}$ & K & $\mathrm{Na}$ & $P$ & $S$ & $\mathrm{Fe}$ & $\mathrm{Cu}$ & $\mathrm{Mn}$ & $\mathrm{Zn}$ & $\mathrm{B}$ \\
\hline & & $\%$ & \multicolumn{5}{|c|}{$\mathrm{cmol}_{\mathrm{c}} \mathrm{kg}^{-1}$} & \multicolumn{7}{|c|}{$\mathrm{mg} \mathrm{kg}^{-1}$} \\
\hline El Retiro 1 & 4.8 & 21 & 1.1 & 2.4 & 0.8 & 0.3 & 0.0 & 2.3 & 6 & 131 & 1.0 & 2.5 & 7.3 & 0.6 \\
\hline El Retiro 2 & 5.1 & 14 & 0.7 & 1.6 & 0.7 & 0.3 & 0.1 & 3.4 & 21 & 144 & 2.1 & 1.3 & 1.3 & 0.3 \\
\hline Rionegro & 5.3 & 17.3 & 0.2 & 3.1 & 1.3 & 0.3 & 0.1 & 3.6 & 8 & 91 & 5.7 & 3.1 & 3.3 & 0.2 \\
\hline El Peñol & 5.1 & 17.3 & 1.1 & 1.4 & 0.6 & 0.4 & 0.0 & 2.7 & 9 & 70 & 2.1 & 3.9 & 1.8 & 0.2 \\
\hline Amaga & 4.9 & 4.8 & 1.7 & 2.1 & 0.7 & 0.4 & 0.0 & 2.8 & 21 & 285 & 2.2 & 3.8 & 1.8 & 0.2 \\
\hline Jardin & 4.9 & 13.2 & 0.9 & 1.4 & 0.8 & 0.6 & 0.1 & 10.4 & 50 & 136 & 5.7 & 13.0 & 12.6 & 0.5 \\
\hline San Pedro 1 & 5.3 & 9.5 & 0.5 & 2.4 & 0.8 & 0.4 & 0.1 & 3.7 & 12 & 266 & 6.2 & 6.3 & 4.5 & 0.2 \\
\hline San Pedro 2 & 5.2 & 10.6 & 0.8 & 1.1 & 0.4 & 0.3 & 0.1 & 2.7 & 7 & 266 & 6.2 & 6.3 & 4.5 & 0.2 \\
\hline
\end{tabular}

pH in water (1:1); Organic Matter Walkley and Black; Al KCI 1M; Ca Mg K and Na ammonium acetate 1M; P Bray II; S Calcium Phosphate 0.008 M; Fe Mn Cu and Zn Olsen-EDTA; B Hot water.

different, being higher in the southwest, in Jardin $(22.76 \mathrm{~kg} /$ plant $)$ and Amaga (19.43 kg/plant), followed by the northern sites, in San Pedro $2(15.75 \mathrm{~kg} /$ plant). Smaller contributions were seen at the locations in eastern Antioquia, such as Rionegro and El Retiro 2 (13.73 and $14.10 \mathrm{~kg} /$ plant, respectively) (Tab. 3). The flower fall was statistically higher in Jardin (754,974 flowers/plant), followed by San Pedro 2, San Pedro 1, and El Peñol (272,360, 210,950 and 198,733, respectively) (Tab. 3).

Table 3. Falling of leaf litter and flowers at different locations over 22 months.

\begin{tabular}{|l|c|c|}
\hline Location & $\begin{array}{c}\text { Leaf dry matter } \\
\text { (kg/plant) }\end{array}$ & $\begin{array}{c}\text { Flowers } \\
\text { (No./plant) }\end{array}$ \\
\hline Retiro 1 & $16.75 \mathrm{~b}$ & $128,912 \mathrm{e}$ \\
\hline Retiro 2 & $14.10 \mathrm{~b}$ & $75,850 \mathrm{~g}$ \\
\hline Rionegro & $13.73 \mathrm{bc}$ & $73,447 \mathrm{~g}$ \\
\hline El Peñol & $17.85 \mathrm{ab}$ & $198,733 \mathrm{~d}$ \\
\hline Amaga & $19.43 \mathrm{ab}$ & $85,963 \mathrm{f}$ \\
\hline Jardin & $22.76 \mathrm{a}$ & $754,974 \mathrm{a}$ \\
\hline San Pedro 1 & $15.35 \mathrm{~b}$ & $210,950 \mathrm{c}$ \\
\hline San Pedro 2 & $15.75 \mathrm{~b}$ & $272,360 \mathrm{~b}$ \\
\hline P-value & $<0.0006$ & $<0.0001$ \\
\hline
\end{tabular}

Means with the same letter do not differ statistically according to Tukey's test $(P \leq 0.05)$

Higher leaf litter contributions occurred in all locations during the driest periods (Fig. 1). The decomposition process of leaf litter returns minerals to plants, from the ground to the aerial part, contributing to metabolic processes; in addition, it improves the physical condition of the soil because it controls weeds, maintains soil humidity in dry seasons, regulates temperature in extreme times and protects it from erosion, as reported in several studies (Moreno et al., 2018; Versini et al., 2014; Lorenzo and Rodríguez-Echavarría, 2015; Bernal and Diaz, 2014).

The origin of avocado in highland tropical rainforests suggests that recycling litter through the detritus food chain has played an important role in its evolution. In fact, there is abundant reason to call this tree a 'litter feeder', with 'feeder' roots that proliferate and absorb released nutrients (Wolstenholme, 1988; Bergh, 1992; Moore-Gordon and Wolstenholme, 1996). Avocados are adapted to soils with surface vegetation litter, or mulch, and a high organic matter content. These conditions provide not only recycled nutrients but also a well-aerated substrate with a high water-holding capacity (WHC) for root growth and a rich microbial microflora (Chandler, 1958).

The location with the highest leaf fall was Jardin (Southwest) with $7.6 \mathrm{t} \mathrm{ha}^{-1}$ year ${ }^{-1}$, followed by Amaga (6.42 $\mathrm{t} \mathrm{ha}^{-1}$ year ${ }^{-1}$ ) and El Retiro 1 (East) (4.03 $\mathrm{t} \mathrm{ha}^{-1}$ year $\left.{ }^{1}\right)$; the dry matter produced in the two northern locations (San Pedro 1 and 2) was very similar, on average $2.8 \mathrm{t} \mathrm{ha}^{-1}$ year $^{-1}$ (Fig. 2). This behavior resulted from the response of the trees to the lack of water since eliminating some leaves reduced losses from transpiration (Schaffer et al., 2015). The leaves that fell were the oldest, with self-shadowing from other leaves that, before falling, translocate a good portion of their mobile nutrients $(\mathrm{N}, \mathrm{P}, \mathrm{K}, \mathrm{Mg}$ ) to new leaves, flowers, or fruits in formation. In this process of senescence, leaves become chlorotic. It is worth noting that non-mobile elements, such as $\mathrm{Ca}$, tend to remain in leaves that fall and have a potential contribution 


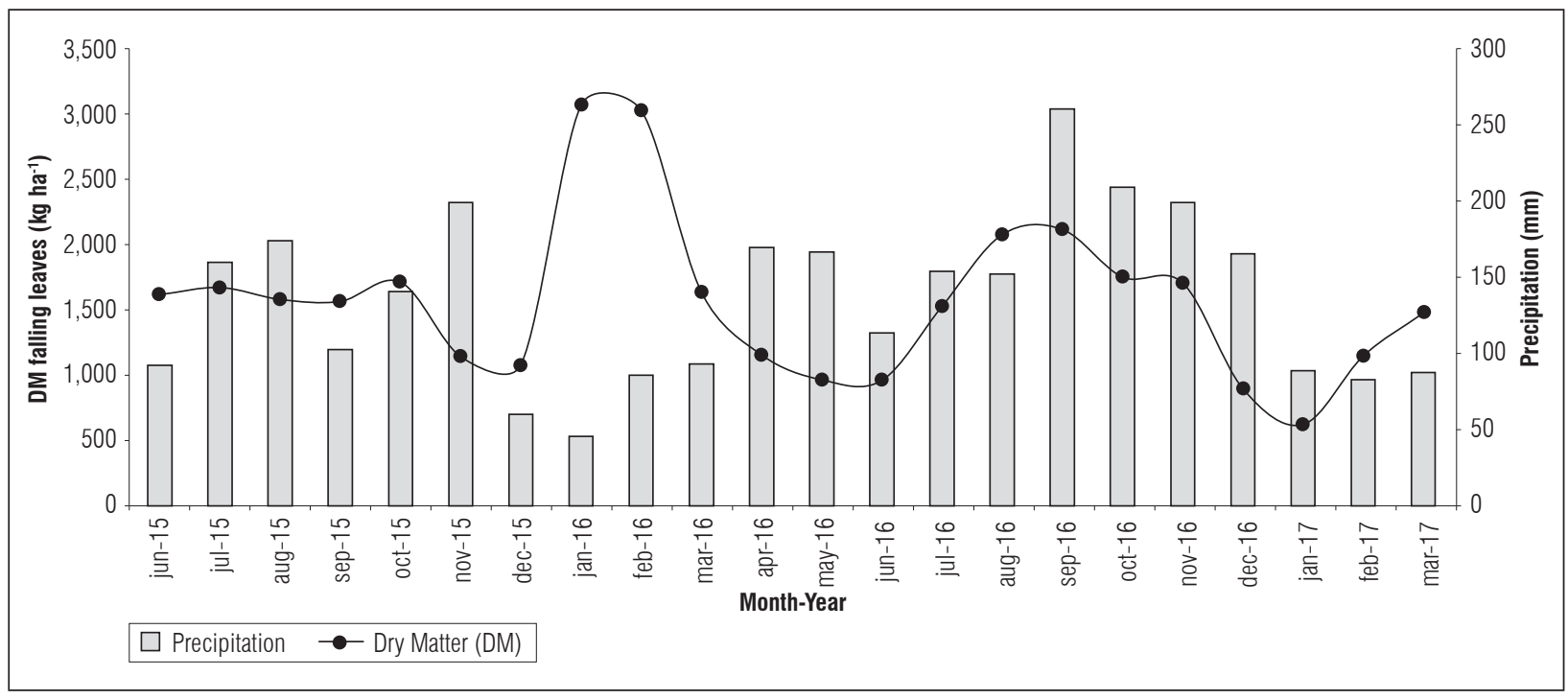

Figure 1. Behavior of the dry matter of the totality of falling leaves, in avocado trees of cv. Hass, planted in eight locations, and rainfall.

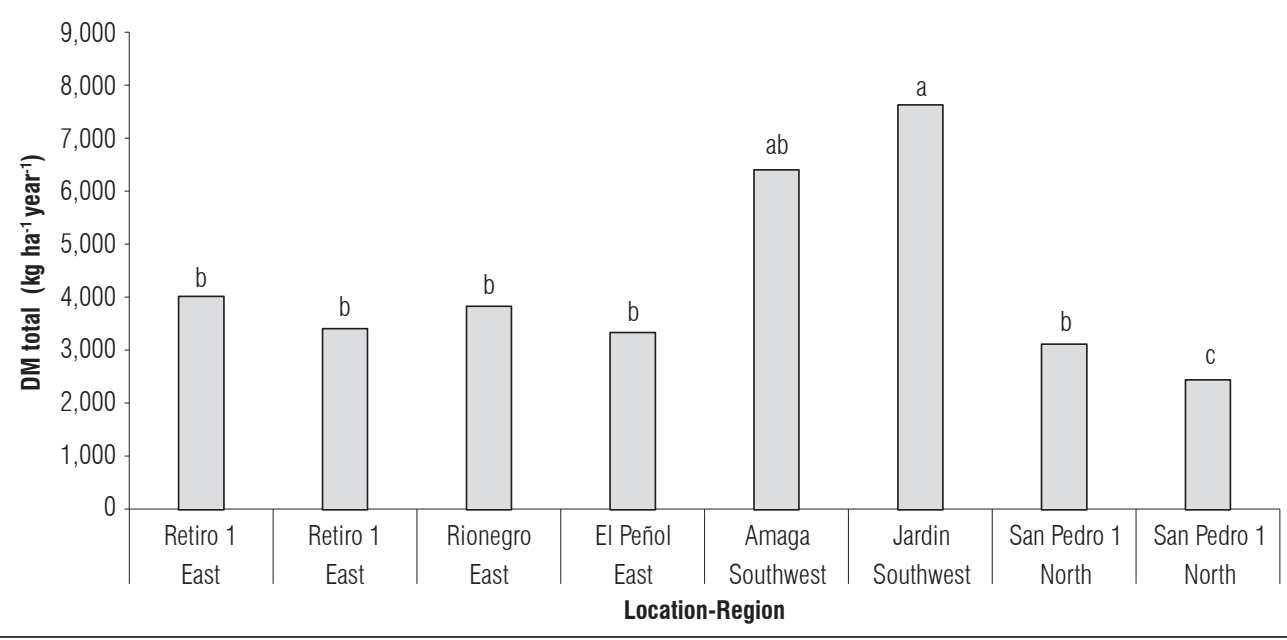

Figure 2. Dry matter behavior of the total fallen leaves in each location for avocado cv. Hass in Antioquia. Means with the same letter do not differ statistically according to Tukey's test $(P \leq 0.05)$.

that tends to be greater; hence, leaf fall litter has a potential contribution of $\mathrm{Ca}$ to the soil (Tamayo-Velez et al., 2019).

Tamayo (2016) studied leaf fall and decomposition in avocado cv. Hass in several locations of Antioquia and found that the general pattern of nutrient release was: $\mathrm{K}>\mathrm{Ca}>\mathrm{Mg}>\mathrm{N}>\mathrm{P}$. In addition, soil fertility parameters changed according to the application of leaf litter inoculated with a saprophyte fungus
(Mortierella sp.); on the other hand, the $\mathrm{pH}$ and contents of $\mathrm{K}, \mathrm{Ca}, \mathrm{Mg}$ and $\mathrm{P}$ increased (Tamayo-Velez et al., 2019).

\section{Flower fall}

Figure 3 shows the locations, with the largest amount found on a farm in the southwest, followed northern Antioquia. In the avocado Hass variety, a tree can 
produce up to 2 million flowers, more than a thousand times the amount of fruit it can bear, but fruit set is only between 0.001 and $0.01 \%$ (Whiley et al., 1988; Dixon and Sher, 2002; Can-Alonzo et al., 2005; Cossio-Vargas et al., 2007; Scora et al., 2013).

\section{Fruit drop}

Avocado trees produce an excessive number of flowers, between 1 and 2 million per tree. However, only one or two fruits of each inflorescence reach maturity (Whiley et al., 1988). In this study, significant differences were found in the number of fallen fruits by location; the municipality of Jardin had 52,926 fallen fruits with less than $0.5 \mathrm{~cm}$, followed by E1 Peñol with 26,744 fallen fruits (Tab. 4); $57 \%$ of the fallen fruits had diameters less than $0.5 \mathrm{~cm}$, and $24 \%$ had diameters between 0.5 and $1 \mathrm{~cm}$, meaning approximately $80 \%$ of the fallen fruits had diameters less than $1 \mathrm{~cm}$ (10\% of its final size). When the fruit started to develop, this falling percentage decreased considerably (Tab. 5).

In general terms, the southwest region (Amaga and Jardin) had the highest average fruit fall $(51,878)$, followed by the northern locations (San Pedro 1 and 2)

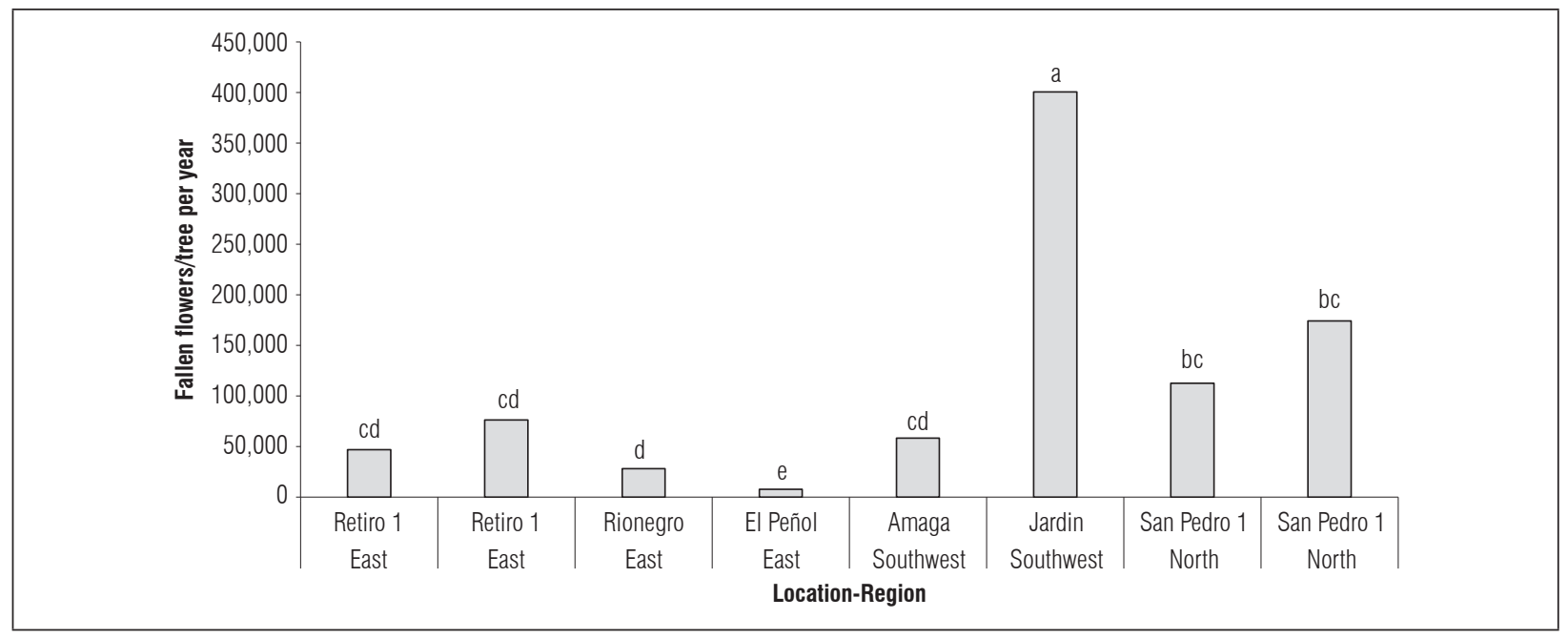

Figure 3. Flower fall by subregion in avocado cv. Hass in Antioquia. Means with the same letter do not differ statistically according to Tukey's test $(\boldsymbol{P} \leq \mathbf{0 . 0 5})$.

Table 4. Number of fallen fruits according to size (diameter, $\mathrm{cm}$ ) and location.

\begin{tabular}{|l|c|c|c|c|c|c|c|c|}
\hline \multicolumn{1}{|c|}{ Location } & $<0.5$ & $0.5-1$ & $1-2$ & $2-3$ & $3-4$ & $4-5$ & $5-6$ \\
\hline & $10,522 \mathrm{~d}$ & $5,463 \mathrm{c}$ & $1,719 \mathrm{~b}$ & $1,062 \mathrm{~b}$ & $766 \mathrm{~b}$ & $28 \mathrm{c}$ & $1 \mathrm{c}$ \\
\hline Retiro 1 & $4,796 \mathrm{e}$ & $1,724 \mathrm{~d}$ & $704 \mathrm{c}$ & $506 \mathrm{c}$ & $174 \mathrm{f}$ & $15 \mathrm{c}$ & $1 \mathrm{c}$ \\
\hline Retiro 2 & $905 \mathrm{f}$ & $1,257 \mathrm{~d}$ & $385 \mathrm{c}$ & $166 \mathrm{de}$ & $141 \mathrm{~g}$ & $29 \mathrm{c}$ & $2 \mathrm{c}$ \\
\hline Rionegro & $26,744 \mathrm{~b}$ & $2,114 \mathrm{~d}$ & $1,462 \mathrm{~b}$ & $273 \mathrm{cde}$ & $374 \mathrm{~d}$ & $93 \mathrm{~b}$ & $15 \mathrm{~b}$ \\
\hline El Peñol & $19,457 \mathrm{c}$ & $7,614 \mathrm{~b}$ & $1,656 \mathrm{~b}$ & $304 \mathrm{~cd}$ & $348 \mathrm{e}$ & $37 \mathrm{c}$ & $18 \mathrm{~b}$ \\
\hline Amaga & $52,926 \mathrm{a}$ & $17,509 \mathrm{a}$ & $4,256 \mathrm{a}$ & $506 \mathrm{c}$ & $449 \mathrm{c}$ & $240 \mathrm{a}$ & $45 \mathrm{a}$ \\
\hline Jardin & $2,504 \mathrm{ef}$ & $548 \mathrm{~d}$ & $407 \mathrm{c}$ & $2,704 \mathrm{a}$ & $1,152 \mathrm{a}$ & $75 \mathrm{~b}$ & $21 \mathrm{~b}$ \\
\hline San Pedro 1 & $8,642 \mathrm{~d}$ & $5,019 \mathrm{c}$ & $1,755 \mathrm{~b}$ & $33 \mathrm{e}$ & $17 \mathrm{~h}$ & $7 \mathrm{c}$ & $1 \mathrm{c}$ \\
\hline San Pedro 2 & $<0.0001$ & $<0.0001$ & $<0.0001$ & $<0.0001$ & $<0.0001$ & $<0.0001$ & $<0.0001$ \\
\hline$P$ & & &
\end{tabular}

Means with the same letter do not differ statistically according to Tukey's test $(P \leq 0.05)$. 
Table 5. Percentage of fallen fruits according to size and location.

\begin{tabular}{|l|c|c|c|c|c|c|c|}
\hline Location & $<0.5 \mathrm{~cm}$ & $0.5-1 \mathrm{~cm}$ & $1-2 \mathrm{~cm}$ & $2-3 \mathrm{~cm}$ & $3-4 \mathrm{~cm}$ & $4-5 \mathrm{~cm}$ & $5-6 \mathrm{~cm}$ \\
\hline Retiro 1 & 53.79 & 27.93 & 8.79 & 5.43 & 3.92 & 0.14 & 0.01 \\
\hline Retiro 2 & 60.56 & 21.77 & 8.89 & 6.39 & 2.20 & 0.19 & 0.01 \\
\hline Rionegro & 31.37 & 43.57 & 13.34 & 5.75 & 4.89 & 1.01 & 0.07 \\
\hline El Peñol & 86.06 & 6.80 & 4.70 & 0.88 & 1.20 & 0.30 & 0.05 \\
\hline Amaga & 66.10 & 25.87 & 5.63 & 1.03 & 1.18 & 0.13 & 0.06 \\
\hline Jardin & 69.70 & 23.06 & 5.61 & 0.67 & 0.59 & 0.32 & 0.06 \\
\hline San Pedro 1 & 33.79 & 7.39 & 5.49 & 36.49 & 15.54 & 1.01 & 0.28 \\
\hline San Pedro 2 & 55.85 & 32.44 & 11.34 & 0.21 & 0.11 & 0.05 & 0.01 \\
\hline \% & 57.15 & 23.60 & 7.97 & 7.11 & 3.70 & 0.39 & 0.07 \\
\hline
\end{tabular}

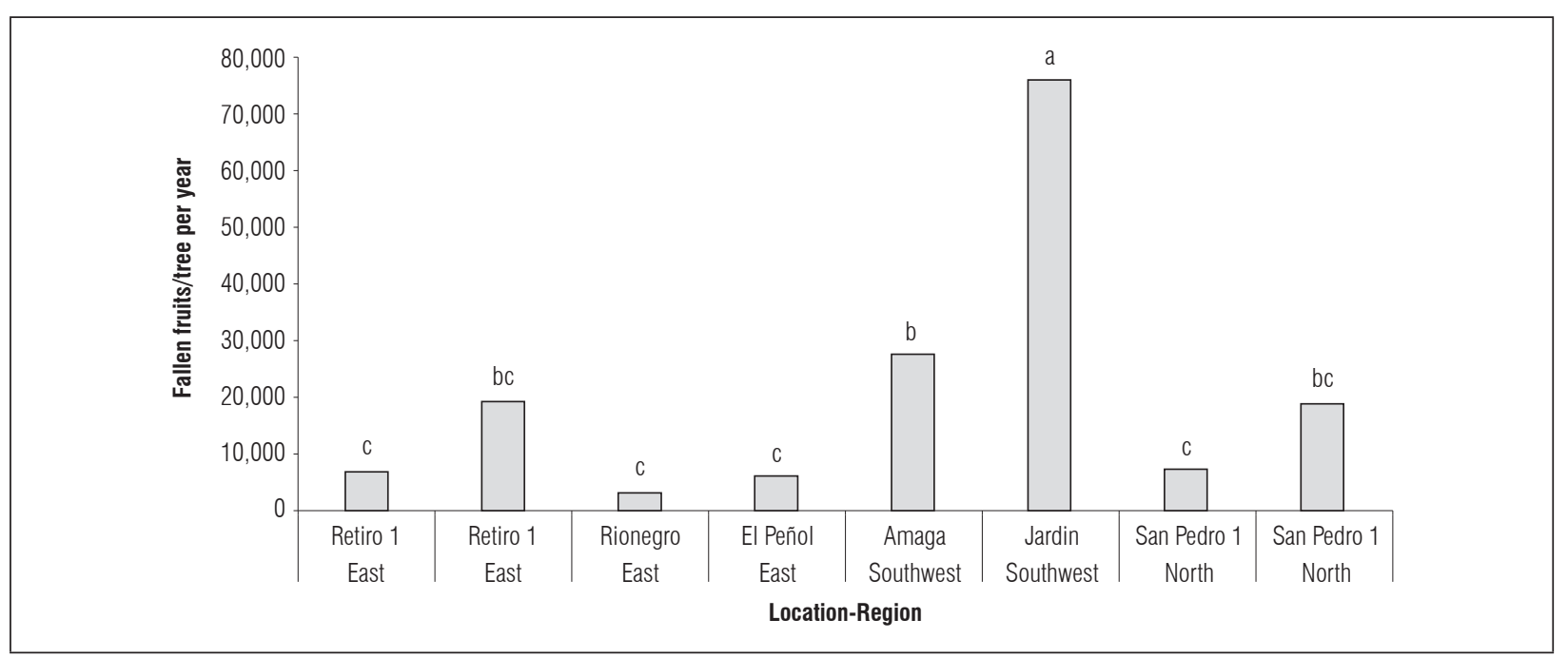

Figure 4. Fruit fall by subregion in avocado cv. Hass in Antioquia. Means with the same letter do not differ statistically according to Tukey's test $(P \leq 0.05)$.

with 13,099 fruits and the eastern region (El Retiro 1 and 2, Rionegro and El Peñol) with 8,844 fruits (Fig. 4). This first fruit fall coincided with the report by Teliz and Mora (2015), who found that the avocado has significant fruit fall because of competition between vegetative growth, root growth and fruit development, directly affecting productivity. Whiley et al. (1988) indicated that avocado plants adjust the capacity to nourish fruits by modifying the number through the massive fall of freshly set fruits during the first three to four weeks and again when fruits reach 10 to $40 \%$ of their size. It should be noted that fruit fall in avocados can be accentuated by a single or excessive application of nitrogen fertilizers when the fruits reach $2 / 3$ or more of their size. Excess nitrogen stimulates a vigorous vegetative flow that exacerbates this problem (Salazar-García, 2007; Salazar-García et al., 2019). The results showed that, under our conditions, there was only a significant fruit drop in the avocado cv. Hass in the first stages of fruit development, unlike that reported by these authors.

Several authors have suggested that the reduced fruit set in avocados is explained by the competition between setting and vegetative growth, which occurs in indeterminate inflorescences. Studies carried out by Cutting and Bower (1990) reinforced this hypothesis, which increased the initial fruit set in indeterminate inflorescences by removing the vegetative bud because of competition for carbohydrates, water or growth regulators, among others (Teliz and Mora, 2015; Salazar-García, 2007). 
Avocado production can be estimated by comparing the energy cost of fructification with the photosynthetic capacity of trees (Wolstenholme, 1986). The avocado fruit is rich in mono- and polyunsaturated fats (oils). Thus, the avocado has an "energy cost" that is higher than the cost of fruits accumulating sugar with a similar weight, as apples or citrus fruits (Teliz and Mora, 2015). The consequence is a lower production per hectare (Wolstenholme, 1986; 1987). If the average potential production of an apple orchard with a high density and intensive management with dwarf rootstocks is $100 \mathrm{t} \mathrm{ha}^{-1}$, the equivalent energy cost for avocados would be $32.5 \mathrm{t} \mathrm{ha}^{-1}$ (Teliz and Mora, 2015). One of the possible causes of low yields in avocados in Colombia and in several producing areas around the world is production that is based on common cultivars, which have a low level of domestication (Wolstenholme and Whiley, 1995; Teliz and Mora, 2015). In high tropical environments in Colombia, the average yields of avocado cv. Hass range between 8 and $12 \mathrm{tha}^{-1}$ although, under optimal conditions of climate, soil, cultivation and management, these yields can double.

\section{CONCLUSIONS}

A higher leaf fall contribution was seen in all locations during the driest periods.

The southwest Antioquia locations had the highest leaf fall (dry matter).

In Antioquia, $57 \%$ of the fallen fruits had diameters smaller than $0.5 \mathrm{~cm}$, and $24 \%$ had diameters between 0.5 and 1 , meaning approximately $80 \%$ of the fallen fruits had diameters less than $1 \mathrm{~cm}$.

Higher amounts of fallen flowers were found in the southwest Antioquia locations, followed by the northern region.

\section{ACKNOWLEDGEMENTS}

The authors thank Agrosavia and the Ministry of Agriculture and Rural Development of Colombia for their financial support.

Conflict of interests: the authors declare that there is no conflict of interests regarding the publication of this paper.

\section{BIBLIOGRAPHIC REFERENCES}

Alvarado-Solano, D.P. and J.T. Otero. 2015. Distribución espacial del Bosque Seco Tropical en el Valle del Cauca, Colombia. Acta Biol. Colomb. 20(3), 141-153. Doi: 10.15446/abc.v20n2.46703

Bergh, B.O. 1992. The origin, nature, and genetic improvement of the avocado. California Avocado Society Yearbook 76, 61-75.

Bernal, J. and C. Díaz. 2014. Actualización tecnológica y buenas prácticas agrícolas (BPA) en el cultivo de Aguacate. Carvajal Soluciones de Comunicación, Medellin, Colombia.

Can-Alonzo, C., J. Quezada-Euán, P. Xiu-Ancona, H. Moo-Valle, G. Valdovinos-Nuñez, and S. Medina-Peralta. 2005. Pollination of 'Criollo' avocados (Persea americana) and the behavior of associated bees in subtropical Mexico. J. Api. Res. 44(1), 3-8. Doi: 10.1080/00218839.2005.11101138

Castellanos, J. and J.D. León. 2011. Descomposición de hojarasca y liberación de nutrientes en plantaciones de Acacia mangium (Mimosaceae) establecidas en suelos degradados de Colombia. Rev. Biol. Trop. 59(1), 113128. Doi: $10.15517 /$ rbt.v59i1.3182

Chandler, W.H. 1958. Evergreen orchards. $2^{\text {nd }}$ ed. Lea and Febiger, Philadelphia.

Charrier, G., J. Ngao, M. Saudreau, and T. Améglio. 2015. Effects of environmental factors and management practices on microclimate, winter physiology, and frost resistance in trees. Front. Plant Sci. 6, 259. Doi: 10.3389/fpls.2015.00259

Cossio-Vargas, L., S. Salazar-García, I. González-Duran, and R. Medina-Torres. 2007. Algunos aspectos reproductivos del aguacate Hass en clima semicálido. p. 11 In: Proc. VI World Avocado Congress. Viña Del Mar, Chile.

Cutting, J.G.M. and J.P. Bower. 1990. Spring vegetative flush removal: The effect on yield, size, fruit mineral composition and quality. South African Avocado Growers' Association Yearbook 13, 33-34.

Dixon, J. and D. Sher. 2002. Pollination of avocados. Annual Research Report of New Zealand Avocado Growers Association 2,1-9.

Dreher, M.L. and A.J. Davenport. 2013. Hass avocado composition and potential health effects. Crit. Rev. Food Sci. Nutr. 53, 738-750. Doi: 10.1080/10408398.2011.556759

FAO. 2019. FAOSTAT - Crops. In: http://www.fao.org/ faostat/es/\#data/QC; consulted: April, 2020.

Fuentes, N., J. Rodríguez, and S. Isenia. 2018. Caída y descomposición de hojarasca en los bosques ribereños del manantial de cañaverales, Guajira, Colombia. Acta Biol. Colomb. 23(1), 115-123. Doi: 10.15446/abc. v23n1.62342 
Gaspar-Santos, E.S., M. González-Espinosa, N. Ramírez-Marcial, and J.D. Álvarez-Solís. 2015. Acumulación y descomposición de hojarasca en bosques secundarios del sur de la Sierra Madre de Chiapas, México. Bosque 36(3), 467-480. Doi: 10.4067/ S0717-92002015000300013

Henao-Rojas, J.C., J.H. Lopez, N.W. Osorio, and J.G. Ramírez-Gil. 2019. Fruit quality in Hass avocado and its relationships with different growing areas under tropical zones. Rev. Ceres 66(5), 341-350. Doi: 10.1590/0034-737x201966050003

Lorenzo, P. and S. Rodríguez-Echeverría. 2015. Soil changes mediated by invasive Australian acacias. Ecosistemas 24(1), 59-66. Doi: 10.7818/ECOS.2015.24-1.10

Loydi, A., K. Lohse, A. Otte, T.W. Donath, and R.L. Eckstein. 2014. Distribution and effects of tree leaf litter on vegetation composition and biomass in a forestgrassland ecotone. J. Plant Ecol. 7(3), 264-275. Doi: 10.1093/jpe/rtt027

MADR, Ministerio de Agricultura y Desarrollo Rural of Colombia. 2019. Anuario estadístico del sector agropecuario 2019. Resultados evaluaciones agropecuarias municipales. In: https://www.agronet.gov.co/estadistica/Paginas/home.aspx?.cod=59; consulted: April, 2020.

Moore-Gordon, C. and B.N. Wolstenholme. 1996. The Hass small fruit problem: role of physiological stress and its amelioration by mulching. South African Avocado Growers' Association Yearbook 19, 82-86.

Moreno, M.E., T.G. Domínguez, M. S. Alvarado, J.G. Colín, S. Corral, and H. González. 2018. Aporte y descomposición de hojarasca en bosques templados de la región de El Salto, Durango. Rev. Mex. Cienc. For. 9(47), 7093. Doi: 10.29298/rmcf.v9i47.180

Ramírez-Gil, J.G., J.C. Henao-Rojas, and J.G. MoralesOsorio. 2020. Mitigation of the adverse effects of the El Niño (El Niño, La Niña). Southern Oscillation (ENSO). Phenomenon and the most important diseases in avocado cv. Hass crops. Plants 9, 790. Doi: 10.3390/plants 9060790

Salazar-García, S. 2007. Floración y fructificación. pp. 6486. In: Teliz, D. and A. Mora (ed.). El aguacate y su manejo integrado. $2^{\text {nd }}$ ed. Mundi-Prensa, México, DC.

Salazar-García, S., L.C. Garner, and C.J. Lovatt. 2015. Biología reproductiva. pp. 151-206. In: Schaffer, B., B.N. Wolstenholme, and A.W. Whiley (eds.). El Aguacate: Botanica, producción y uses. $2^{\text {nd }}$ ed. Ediciones Universitarias de Valparaiso, Valparaiso, Chile.

Salazar-García, S., A. Álvarez-Bravo, M.E. Ibarra-Estrada, and A. Mellado-Vázquez. 2019. Accumulation of nutrients during the development of 'Méndez' avocado fruit. Terra Latinoam. 37(4), 469-478. Doi: 10.28940/ terra.v37i4.547
Schaffer, B., P.M. Gil, M.B. Mickelbart, and A.W. Whiley. 2015. Ecofsiología. pp. 207-242. In: Schaffer, B., B.N. Wolstenholme, and A.W. Whiley (eds.). El aguacate: Botanica, producción y uses. $2^{\text {nd }}$ ed. Ediciones Universitarias de Valparaiso, Valparaiso, Chile.

Scora, R.W., B.N. Wolstenholme, and U. Lavi. 2013. Taxonomy and botany. pp. 15-37. In: Whiley, A.W., B. Schaffer, and B.N. Wolstenholme (eds.). The avocado: Botany, production and uses. CABI Publishing, Wallingford, UK. Doi: 10.1079/9780851993577.0015

Tamayo, A. 2016. Descomposición de hojarasca y liberación de nutrientes en plantaciones de aguacate cv. Hass en función de la inoculación con un hongo saprofito en tres pisos térmicos. $\mathrm{PhD}$ thesis. Faculty of Agriculture Sciences, Universidad Nacional de Colombia, Medellin, Colombia.

Tamayo, A. and W. Osorio 2014. Nutrición y fertilización. pp. 182-212. In: Bernal A. and C. Díaz (eds.). Manual técnico Actualización Tecnológica y buenas Prácticas Agrícolas (BPA) en el cultivo del aguacate. Carvajal Soluciones de Comunicación, Medellin, Colombia.

Tamayo-Vélez, Á., G. Correa-Londoño, and N.W. Osorio. 2019. Inoculation with a soil fungus accelerates decomposition of avocado cv. Hass leaf litter in three plantations in Colombia. AUC Geogr. 54(1), 23-35 Doi: $10.14712 / 23361980.2019 .3$

Teliz, D. and A. Mora. 2015. El aguacate y su manejo integrado. Ed. Colegio de postgraduados. México, DC.

Tixier, A., P. Guzmán-Delgado, O. Sperling, A.A. Roxas, E. Laca, and M.A. Zwieniecki. 2020. Comparison of phenological traits, growth patterns, and seasonal dynamics of non-structural carbohydrate in Mediterranean tree crop species. Sci. Rep. 10(1), 347. Doi: 10.1038/ s41598-019-57016-3

Versini, A., B. Zeller, D. Derrien, J.C. Mazoumbou, L. Mareschal, L. Saint-André, and P. Laclau. 2014. The role of harvest residues to sustain tree growth and soil nitrogen stocks in a tropical Eucalyptus plantation. Plant Soil 346, 245-260. Doi: 10.1007/s 111 04-013-1963-y

Whiley, A.W. 1994. Ecophysiological studies and tree manipulation for maximization of yield potential in avocado (Persea americana Mill.). PhD thesis. University of Natal, Pietermaritzburg, South Africa.

Whiley, A.W., J.B. Saranah, B.W. Cull, and K.G. Pegg. 1988. Manage avocado tree growth cycles for productivity gains. Queensl. Agr J. 114, 29-36.

Whiley, A.W. and B. Schaffer. 1994. Avocado. pp. 165-197. In: Schaffer, B. and P.C. Andersn (eds.). Handbook of environmental physiology of fruit crops. Subtropical and Tropical Crops. CRC Press, Boca Raton, FL. 
Wolstenholme, B.N. 1986. Energy costs of fruiting as a yield-limiting factor, with special reference to avocado. Acta Hortic. 175, 121-126. Doi: 10.17660/ ActaHortic.1986.175.18

Wolstenholme, B.N. 1987. Theoretical and applied aspects of avocado yield as affected by energy budgets and carbon partitioning. In: Proc. $1^{\text {st }}$ World Avocado Congress. South African Avocado Growers' Association Yearbook 1987(10), 58-61.
Wolstenholme, B.N. 1988. An overview of avocado technology towards 2000. pp. 4-13. In: Proc. Australian Avocado Bicentennial Conference. Caloundra, Queensland,

Wolstenholme, B. and A.W. Whiley. 1995. Strategies for maximizing avocado productivity: An overview. pp. 61-70. In: Proc. III World Avocado Congress. Tel Aviv, Israel. 